\title{
Investigation of Toxicological Properties of P(3HB-co-4HB) Electrospun Membranes as an Experimental Wound Dressings
}

\author{
Ekaterina I. Shishatskaya* \\ Siberian Federal University \\ 79 Svobodny, Krasnoyarsk, 660041, Russia \\ Institute of Biophysics SB RAS \\ Federal Research Center \\ "Krasnoyarsk Science Center SB RAS" \\ 50/50 Akademgorodok, Krasnoyarsk, 660036, Russia
}

Received 26.03.2017, received in revised form 05.05.2017, accepted 14.05.2017

\begin{abstract}
Non-woven experimental samples of wound dressings, made from natural degradable polymers, were produced and investigated. High-porous membranes were obtained by electrostatic formation of solutions of copolymers of 3-hydroxybutyrate-co-4-hydroxybutyrate [P(3HB-co-4HB)]. The set of pre-clinical assessments was performed, included testing of membranes in vitro and in vivo. Study was carried out by staining of blood cells with vital fluorochromic dyes, followed by analysis of activation of platelet adhesion, the ratio of the main morphological types of erythrocytes, measurements of changes of hemoglobin content in human blood, and hemolytic activity. The general toxic effect was investigated in experiment with white mice after the intraabdominal injection of water extracts of membranes. It was established, that direct contact with membranes had no negative influence towards cells of blood and showed no toxic effects in animal experiments.
\end{abstract}

Keywords: non-woven wound dressings, electrospinning, copolymers [P(3HB-co-4HB)], toxicology.

Citation: Shishatskaya E.I. Investigation of toxicological properties of $\mathrm{P}(3 \mathrm{HB}-\mathrm{co}-4 \mathrm{HB})$ electrospun membranes as an experimental wound dressings. J. Sib. Fed. Univ. Biol., 2017, 10(2), 237-245. DOI: 10.17516/1997-1389-0026.

(C) Siberian Federal University. All rights reserved

* Corresponding author E-mail address: shishatskaya@inbox.ru 


\title{
Исследование токсикологических свойств \\ Р(3НВ-со-4НВ) нетканых мембран \\ в качестве экспериментальных раневых покрытий
}

\author{
Е.И. Шишацкая \\ Сибирский федеральньй университет \\ Россия, 660041, Красноярск, пр. Свободный, 79 \\ Институт биофизики СО РАН \\ Федеральный исследовательский центр \\ «Красноярский научный центр СО РАН» \\ Россия, 660036, Красноярск, Академгородок, 50/50
}

Изготовлены и исследованы нетканые экспериментальные образцы раневых покрытий из природных биоразлагаемых полимеров. Мембраны получены способом электростатического формования растворов сополимера 3-гидроксибутирата-со-4-гидроксибутирата [П(3ГБсо-4ГБ)]. Проведено комплексное доклиническое исследование, включающее тестирование мембран in vitro $u$ in vivo. Исследование выполнено окрашиванием клеток крови витальными флуорохромными красителями с последующзим анализом активации тромбициитов, количества морфологических типов эритроцитов, а также содержания гемоглобина в крови и гемолитического действия. Общетоксическое действие исследовано в эксперименте на бельх мышиах при внутрибрюшинном введении водных экстрактов мембран. In vitro показано, что прямой контакт с тестируемыми мембранами не оказывал отрицательного влияния на клетки крови и не проявлял токсических эффектов на животных.

Ключевые слова: нетканые раневые покрытия, электростатическое формование, сополимеры [П(3ГБ-со-4ГБ)], токсикологические исследования.

\section{Introduction}

Reconstructive medicine needs novel materials for effective regeneration of skin injured due to burns, traumas and surgical interventions. There are hundreds of surgical and therapeutic devices for covering and healing skin defects and a great number of materials and drugs used to prepare these devices. The ideal wound dressing must fulfill normal functions of healthy skin, which includes antimicrobial potential, promote moist wound environment, permit exchange of gases, provide mechanical protection and be sufficiently elastic to fit the wound shape. One of the major challenges is to choose an ideal material, which can be processed and shaped as 3D-constructs.

One of the main factors in bioengineering of artificial tissues, determining successful formation of new tissue, is the adequate scaffold material. Among the most promising cell scaffolds for derma restoration, nonwoven polymer membranes, produced by electrospinning, demonstrate better mechanical and biological properties, so as they have similar structure to that of mesh layer of derma, forming with the interlacing of collagen and elastin fibers (Sill, von Recum, 2008; Sharma et al., 2014). Electrospinning, electrostatic formation (ESF), can be used to produce 
3D-open porous structures, using solutions of high molecular weight compounds, including natural polymeric materials, such as collagen and chitosan, or synthetic polymers, mostly often poly-L-lactide (PLLA), polycaprolactone (PCL) and polyglycolic acid (PGA). Recent reviews highlight, that ES-scaffolds from PHAs facilitate proliferation of cells of various types, including fibroblasts, osteoblasts, chondrocytes, neurons, and stem cells also. Thus, there is a promising future for PHAs as a materials for the development of scaffolds for skin substitution and Degradable Wound dressings. The goal of the investigation was to test high-porous ESmembranes from two-component co-polymer of PHAs, 3-hydroxybutyrate-co-4-hydroxybutyrate [P(3HB-co-4HB)], intended for skin wounds repair.

In accordance with the international systems of estimation of products, intended for the contact with the body and biological mediums, they must had no hazard effect and be examined with specific tests, depending on the purpose of the application. There are distinct requirements for toxicological safety for the medical materials, intended for prolonged direct contact with opened wound. Initial estimation of non-woven membranes included approaches with use of blood cells and protein, and toxicological studies in vivo, using small laboratory animals.

\section{Materials and methods}

Samples of ESF-nonwoven membranes of two types, made from randomly oriented and aligned fibers, were prepared by electrospinning of copolymers of $\mathrm{P}(3 \mathrm{HB}-\mathrm{co}-4 \mathrm{HB}) \quad 2-6$ wt \% solutions, using a Nanon 01A automatic setup (MECC Inc., Japan). Resulting filaments of polymers were collected onto the target with the oriented or random manner; the solution feeding rate was $8 \mathrm{ml} / \mathrm{h}$, the applied voltage $25 \mathrm{kV}$, and the working distance to the target $15 \mathrm{~cm}$.
To assess the biological safety of non-woven membranes, human blood cells were used - red blood cells from whole donor blood and the donor red blood cells mass, and platelets also from whole blood of donors and donors platelet mass (GOST R ISO 10993-4-2011, part 4). Study was carried out by staining of blood cells with vital fluorochromic dyes, followed by analysis of activation of platelet adhesion (Khubutija et al., 2013), the ratio of the main morphological types of erythrocytes, measurements of changes of hemoglobin content in blood, and hemolysis. Determination of free hemoglobin was carried out spectrophotometrically, according to the method (Harboe, 1959). In vivo tests of general toxic effects were performed on laboratory animals according to (GOST R ISO 10993-2-2009, part 2; GOST R ISO 10993-11-2011, part 11), with the permission of the Ethical commission of SibFU. General toxicity of extracts of the membranous samples was studied in white mice, weighing 21$25 \mathrm{~g}$, experimentation included per 10 animals in in experimental and control groups. Animals were injected intraperitoneally with membranes water extracts in the dose $1 \mathrm{ml} / 10 \mathrm{~g}$ of body weight, with the temperature $37 \pm 1.5^{\circ} \mathrm{C}$. Control animals received distilled water the same way. The results were processed statistically with Microsoft Excel application package; the arithmetic mean and standard deviation were calculated.

\section{Results and discussion}

Nonwoven membranes were fabricated from $\mathrm{P}(3 \mathrm{HB}-\mathrm{co}-4 \mathrm{HB})$ solutions with polymer concentrations between 2 and $6 \mathrm{wt} \%$ and viscosity $200-600 \mathrm{cP}$ by stable electrospinning using a Nanon 01A set-up. Polymer concentration had significant influence to the diameter of the ultrafine fibers (Fig. 1). The orientation of fibers in membrane and its diameter significantly influenced to the physical-mechanical properties of membranes. The tensile strength and Young's 


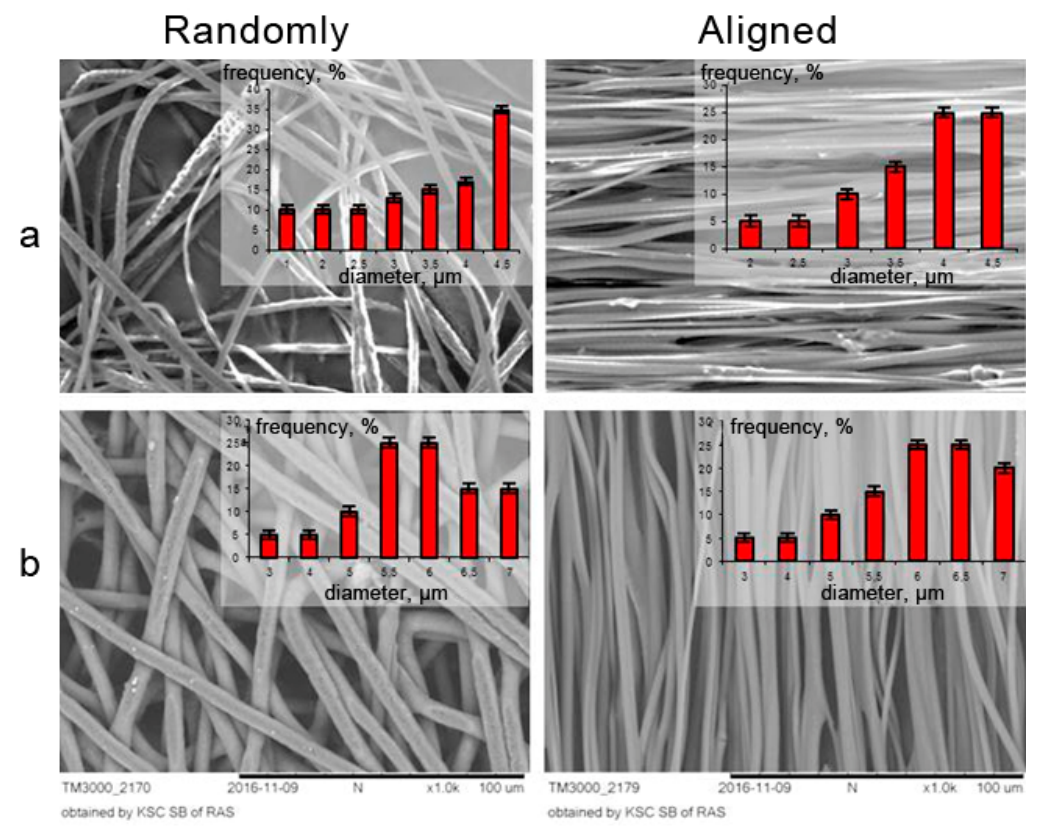

Fig 1. SEM-images and fiber diameter distribution of nonwoven membranes, made from randomly oriented and aligned ultrafine fibers, obtained by electrospinning of $2 \%$ (a) and $6 \%$ (b) solutions of $\mathrm{P}(3 \mathrm{HB}-\mathrm{co}-4 \mathrm{HB})$

Table 1. Physico - mechanical properties of nonwoven membranes of $\mathrm{P}(3 \mathrm{HB}-\mathrm{co}-4 \mathrm{HB})$

\begin{tabular}{|c|c|c|c|}
\hline $\begin{array}{c}\text { Solutions of copolymers } \\
\text { of P(3HB-co-4HB), } \%\end{array}$ & Young's modulus, E, MPa & Tensile strength, $\sigma, \mathrm{MPa}$ & Elongation at break, $\varepsilon, \%$ \\
\hline \multicolumn{4}{|c|}{ randomly oriented fibers } \\
\hline 2.0 & $3.61 \pm 0.78$ & $0.82 \pm 0.09$ & $98.95 \pm 6.31$ \\
\hline 6.0 & $2.22 \pm 0.28$ & $1.46 \pm 0.21$ & $127.74 \pm 16.07$ \\
\hline \multicolumn{4}{|c|}{ aligned fibers } \\
\hline \multicolumn{5}{|c|}{$17.50 \pm 1.81$} & $15.33 \pm 3.29$ & $113.10 \pm 10.20$ \\
\hline 6.0 & $15.50 \pm 2.08$ & $11.91 \pm 1.63$ & $115.90 \pm 19.45$ \\
\hline
\end{tabular}

modulus of the membranes from aligned fibers was significantly higher, then the values of membranes from randomly oriented fibers (Table 1). The tensile strength of samples with aligned fibers was almost 10 times higher, than that of samples with randomly oriented fibers. On the other hand, fiber orientation had little if any influence on the elastic properties of samples, the parameter was of $98.95-127.74 \%$.

Surface properties of nonwoven membranes of copolymers $\mathrm{P}(3 \mathrm{HB}-\mathrm{co}-4 \mathrm{HB})$ are listed in
Table 2. Membranes, consisting of the smallestdiameter fibers $(0.60-0.65 \mu \mathrm{m})$ had the lowest values of the water contact angle, $51.20-52.23^{\circ}$. So, the orientation of fibers in membranes did not influence their surface properties. Similar values of surface tension, interfacial free energy, and cohesive force properties of the membranes, calculated on the water contact angle, were demonstrated.

During the investigation it was revealed, that the direct contact of polymeric membranous 
Table 2. Surface properties of nonwoven membranes comprised of ultrafine fibers with different diameters, electrospun from $\mathrm{P}(3 \mathrm{HB}-\mathrm{co}-4 \mathrm{HB})$ solutions

\begin{tabular}{|c|c|c|c|c|}
\hline Fiber diameter, $\mu \mathrm{m}$ & $\begin{array}{c}\text { Water contact angle, } \\
\theta,{ }^{\circ}\end{array}$ & $\begin{array}{c}\text { Surface tension, } \gamma, \\
\mathrm{erg} / \mathrm{cm}^{2}\end{array}$ & $\begin{array}{c}\text { Interfacial free } \\
\mathrm{energy}, \gamma_{\mathrm{SL}}, \mathrm{erg} / \mathrm{cm}^{2}\end{array}$ & $\begin{array}{c}\text { Cohesive force, } W_{\mathrm{SL},} \\
\mathrm{erg} / \mathrm{cm}^{2}\end{array}$ \\
\hline \multicolumn{5}{|c|}{ randomly oriented fibers } \\
\hline $0.65 \pm 0.10$ & $51.20 \pm 1.06$ & 68.54 & 2.54 & 118.42 \\
$3.34 \pm 0.24$ & $68.23 \pm 0.31$ & 73.64 & 7.20 & 99.80 \\
\hline \multicolumn{5}{|c|}{ aligned fibers } \\
\hline $0.65 \pm 0.12$ & $52.23 \pm 0.70$ & 68.88 & 2.73 & 117.39 \\
$3.14 \pm 0.38$ & $68.80 \pm 0.26$ & 73.79 & 7.42 & 99.13 \\
\hline
\end{tabular}
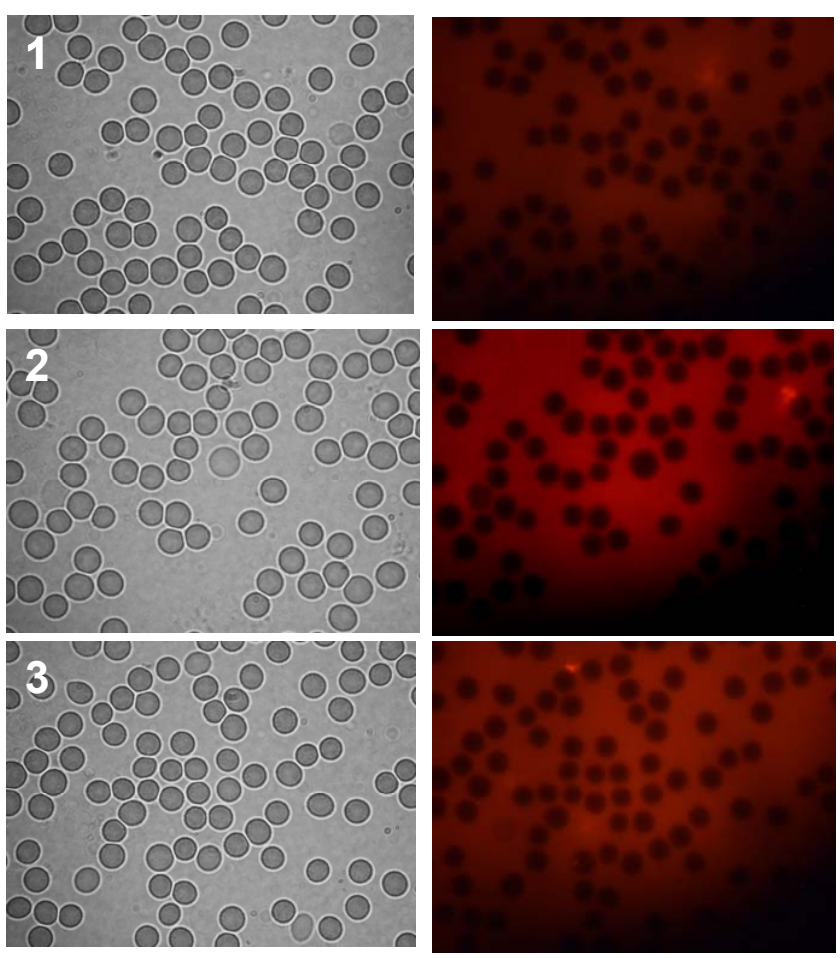

Fig. 2. Human erythrocytes: 1 - in the intact erythromass, 2 and 3 - after the contact with oriented and non-oriented membranes from $\mathrm{P}(3 \mathrm{HB}-\mathrm{co}-4 \mathrm{HB})$; $\mathrm{a}$ - cells in transmitted light, $\mathrm{b}$ - fluorescence of vital fluorochromic dye. Magnification x 800

samples does not reduce the biological value of the blood cells (Fig. 2-3, Tables 3-5). Foremost, non-woven polymeric membranes did not have a negative effect towards erythrocytes. The number of damaged erythrocytes upon contact with $\mathrm{P}(3 \mathrm{HB}-\mathrm{co}-4 \mathrm{HB})$ membranes wasn't higher than in the control samples of intact erythromass (Table 3, Fig. 2). Non-woven polymeric membranes did not have any destroying effect on erythrocytes integrity with two temperature regimes $-22^{\circ} \mathrm{C}$ for 10 minutes, 1 and 24 hours; $37^{\circ} \mathrm{C}$ for 10 minutes and 1 hour.

For samples of oriented non-woven membranes, adhesion of all 3 types of blood cells was completely absent, regardless of the timing of exposure. Samples of non-oriented membranes 


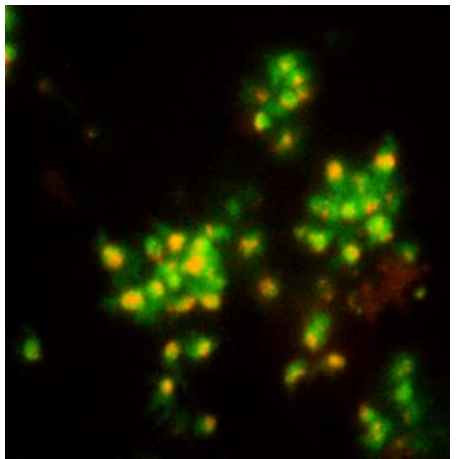

a

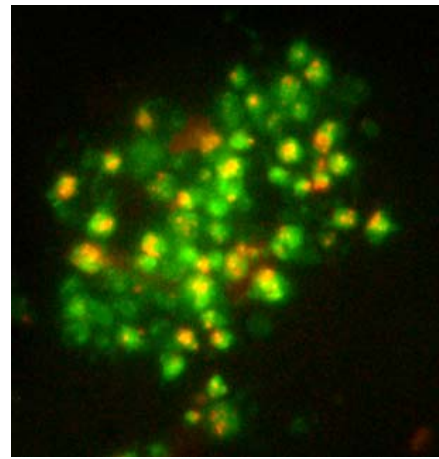

b

Fig. 3. Vitally stained platelets of human plasma before (a) and after (b) contact with nonwoven membranes from $\mathrm{P}(3 \mathrm{HB}-\mathrm{co}-4 \mathrm{HB})$ : preservation of the general form of platelets, internal composition (platelet granules) and cell glowing intensity. Magnification x1000

Table 3. Assessment of biological value of human red blood cells after the contact with $\mathrm{P}(3 \mathrm{HB}-\mathrm{co}-4 \mathrm{HB})$ membranes

\begin{tabular}{|c|c|c|c|c|c|c|c|}
\hline & \multirow{4}{*}{ 3HB-co-4HB) membranes } & \multicolumn{6}{|c|}{ Erythrocytes during the direct contact with nonwoven membranes } \\
\hline & & \multirow{3}{*}{$\begin{array}{c}\text { Before } \\
\text { the } \\
\text { contact }\end{array}$} & \multicolumn{3}{|c|}{$22^{\circ} \mathrm{C}$} & \multicolumn{2}{|c|}{$37^{\circ} \mathrm{C}$} \\
\hline & & & \multicolumn{3}{|c|}{ Contact time } & \multicolumn{2}{|c|}{ Contact time } \\
\hline & & & $10 \mathrm{~min}$ & $1 \mathrm{~h}$ & $24 \mathrm{~h}$ & $10 \mathrm{~min}$ & $1 \mathrm{~h}$ \\
\hline \multirow{3}{*}{ 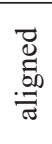 } & Normal cells, $\%$ & 85.0 & 85.0 & 85.0 & 84.7 & 84.8 & 84.7 \\
\hline & Changed/damaged cells, $\%$ & 11.9 & 11.9 & 11.8 & 12.1 & 11.9 & 11.6 \\
\hline & Dead cells, $\%$ & 3.1 & 3.1 & 3.2 & 3.2 & 3.3 & 3.7 \\
\hline \multirow{3}{*}{ 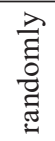 } & Normal cells, $\%$ & 85.0 & 85.0 & 85.0 & 84.7 & 84.8 & 84.7 \\
\hline & Changed/damaged cells, $\%$ & 11.9 & 11.9 & 11.8 & 12.1 & 11.9 & 11.6 \\
\hline & Dead cells, \% & 3.1 & 3.1 & 3.2 & 3.2 & 3.3 & 3.7 \\
\hline
\end{tabular}

Table 4. Spectrophotometric determination of free hemoglobin in whole blood after the contact with $\mathrm{P}(3 \mathrm{HB}-\mathrm{co}-$ 4HB) membranes

\begin{tabular}{|c|c|c|c|c|}
\hline \multirow{2}{*}{ Variant } & \multicolumn{3}{|c|}{ Wavelength } & \multirow{2}{*}{$\mathrm{C}_{\mathrm{Hb}}, \mathrm{g} / \mathrm{L}$} \\
\cline { 2 - 4 } & $380 \mathrm{~nm}$ & $415 \mathrm{~nm}$ & $450 \mathrm{~nm}$ & 0.2317 \\
\hline Control (culture plastic) & 0.0435 & 0.1709 & 0.0212 & \\
Nonwoven membranes & & & & 0.2331 \\
aligned fibers & 0.0428 & 0.1703 & 0.0190 & 0.2364 \\
\hline randomly oriented fibers & 0.0432 & 0.1727 & 0.0194 & \\
\hline
\end{tabular}

completely lacked adhesion of erythrocytes, and revealed very unexpressed adhesion of platelets, less than 0.01 thousand per $1 \mathrm{~cm}^{2}$, which was not accompanied by their activation and damage, i.e., it seems, that such slight platelets adhesion should be evaluated as passive adhesion or adsorption of cells, not related to adhesive activity of the material. 
Table 5. Results of the estimation of the hemolytic activity of extracts from nonwoven $\mathrm{P}(3 \mathrm{HB}-\mathrm{co}-4 \mathrm{HB})$ membranes

\begin{tabular}{|c|c|}
\hline Variant & Hemolytic activity \\
\hline Control $(0,9 \% \mathrm{NaCl})$ & $0.25 \%$ \\
$\mathrm{P}(3 \mathrm{HB}-\mathrm{co}-4 \mathrm{HB})$ nonwoven membranes & \\
Aligned fibers & $0.10 \%$ \\
Randomly oriented fibers & $0.06 \%$ \\
\hline
\end{tabular}

Table 6. Platelet adhesion to the membranes of two types of fibers orientation. The estimation of adhesion properties after contact with nonwoven membranes

\begin{tabular}{|c|c|c|c|c|c|c|}
\hline \multirow{4}{*}{$\begin{array}{c}\text { Nonwoven membranes from } \\
\text { P(3HB-co-4HB) }\end{array}$} & \multicolumn{6}{|c|}{$\begin{array}{l}\text { Number of adhered platelets }\left(10^{3} / \mathrm{sm}^{2}\right) \text { during the direct contact with } \\
\text { membranes }\end{array}$} \\
\hline & \multirow{3}{*}{$\begin{array}{c}\text { Before } \\
\text { the } \\
\text { contact }\end{array}$} & \multicolumn{3}{|c|}{$22^{\circ} \mathrm{C}$} & \multicolumn{2}{|c|}{$37^{\circ} \mathrm{C}$} \\
\hline & & \multicolumn{3}{|c|}{ Contact time } & \multicolumn{2}{|c|}{ Contact time } \\
\hline & & $10 \mathrm{~min}$ & $1 \mathrm{~h}$ & $24 \mathrm{~h}$ & $10 \mathrm{~min}$ & $1 \mathrm{~h}$ \\
\hline Aligned fibers & - & 0 & 0 & 0 & 0 & 0 \\
\hline Randomly oriented fibers & - & 0 & 0.006 & 0.007 & 0 & 0 \\
\hline
\end{tabular}

The hemoglobin content in the blood when it came into contact with samples of the test non-woven membranes, also did not change (Table 4).

Evaluation of hemolytic effect of aqueous extracts of experimental samples of wound dressings was carried out with whole human donor blood. Mixture of water extracts, prepared, as described before, with whole blood, were made, and optical density of the solution was measured, relatively the $100 \%$ hemolysis in the control, obtained with a sterile hypertonic saline solution.

Extracts from both types of membranes did not provoke a hemolytic effect on erythrocytes, the hemolytic activity in both experimental group was $0.06-0.10 \%$, with an allowable level of index for wound dressings and other surgical materials is of up to $2 \%$ (Table 5 ).

Special mention should be made of the results of the study of platelets, since these cells are very sensitive to changes in the conditions of their contents and high damage; in addition, the high ability of platelets to adhere to any surfaces, including biomaterials, is known. The morphology of platelets, contacted with the test samples of nonwoven membranes did not change, compared to the control - platelets of human plasma before the contact with the samples (Fig. 3).

The number of adhered platelets to the surface of membranes was counted compared to the value before the contact; there were no differences between control and experimental samples (Table 6).

Thus, the investigated samples of non-woven polymeric membranes as wound coatings have not activating influence for blood cells.

The general toxic effect of $\mathrm{P}(3 \mathrm{HB}-\mathrm{co}-4 \mathrm{HB})$ membranes was investigated in a short-term 7-day experiment with white mice after the intraabdominal injection of water extracts of membranes. Throughout the observation time, the animals did not exhibit any intoxication reactions. The behavior of the experimental mice was similar to that of the controls. The body 
Table 7. The estimation of toxic effect of aqueous extracts from $\mathrm{P}(3 \mathrm{HB}-\mathrm{co}-4 \mathrm{HB})$ membranes in experiments with white mice $(\mathrm{M} \pm \mathrm{m})$

\begin{tabular}{|c|c|c|c|c|}
\hline \multirow{2}{*}{ Parameter } & Intact control & $\begin{array}{c}\text { Positive control } \\
\left(\mathrm{H}_{2} \mathrm{O}\right)\end{array}$ & \multicolumn{2}{|c|}{ P(3HB-co-4HB) membranes } \\
\cline { 3 - 5 } & & Bligned fibers & $\begin{array}{c}\text { Randomly oriented } \\
\text { fibers }\end{array}$ \\
\hline \multicolumn{5}{|c|}{ Body weight $(\mathrm{g})$} \\
\hline Initial & $23.20 \pm 0.16$ & $22.44 \pm 0.13$ & $23.54 \pm 0.20$ & $23.60 \pm 0.19$ \\
End of experiment & $26.10 \pm 0.32$ & $25.07 \pm 0.45$ & $26.33 \pm 0.36$ & $26.10 \pm 0.39$ \\
\hline \multicolumn{5}{|c|}{ Mass of organs $(\mathrm{g})$} \\
Liver & $1.19 \pm 0.04$ & $1.20 \pm 0.03$ & $1.24 \pm 0.05$ & $1.21 \pm 0.04$ \\
Kidneys & $0.15 \pm 0.01$ & $0.14 \pm 0.01$ & $0.15 \pm 0.00$ & $0.15 \pm 0.01$ \\
Lungs & $0.33 \pm 0.02$ & $0.34 \pm 0.01$ & $0.34 \pm 0.03$ & $0.35 \pm 0.02$ \\
Heart & $0.20 \pm 0.02$ & $0.20 \pm 0.02$ & $0.21 \pm 0.02$ & $0.21 \pm 0.02$ \\
\hline
\end{tabular}

Table 8. Cells composition of peripheral blood of mice on day 7 after the injection of aqueous extracts from $\mathrm{P}(3 \mathrm{HB}-\mathrm{co}-4 \mathrm{HB})$ membranes $(\mathrm{M} \pm \mathrm{m})$

\begin{tabular}{|c|c|c|c|c|}
\hline \multirow[b]{2}{*}{ Cells } & \multirow[b]{2}{*}{ Intact control } & \multirow{2}{*}{$\begin{array}{l}\text { Positive control } \\
\qquad\left(\mathrm{H}_{2} \mathrm{O}\right)\end{array}$} & \multicolumn{2}{|c|}{$\mathrm{P}(3 \mathrm{HB}-\mathrm{co}-4 \mathrm{HB})$ membranes } \\
\hline & & & Aligned fibers & $\begin{array}{c}\text { Randomly oriented } \\
\text { fibers }\end{array}$ \\
\hline Erythrocytes, $10^{9} / \mathrm{ml}$ & $8.05 \pm 0.03$ & $7.99 \pm 0.04$ & $8.00 \pm 0.03$ & $7.99 \pm 0.04$ \\
\hline Leukocytes, $10^{9} / \mathrm{ml}$ & $7.65 \pm 0.06$ & $7.57 \pm 0.08$ & $7.57 \pm 0.06$ & $7.67 \pm 0.07$ \\
\hline Stab neutrophils, $\%$ & $2.50 \pm 0.52$ & $3.57 \pm 0.48$ & $4.00 \pm 0.69$ & $6.71 \pm 0.58$ \\
\hline $\begin{array}{c}\text { Segmental } \\
\text { leukocytes, \% }\end{array}$ & $48.00 \pm 2.30$ & $54.00 \pm 2.14$ & $46.71 \pm 2.52$ & $49.00 \pm 2.28$ \\
\hline Lymphocytes, \% & $40.50 \pm 2.42$ & $39.43 \pm 1.95$ & $41.43 \pm 2.53$ & $37.62 \pm 2.34$ \\
\hline Monocytes, \% & $9.00 \pm 0.67$ & $7.86 \pm 0.80$ & $7.86 \pm 0.46$ & $6.72 \pm 0.71$ \\
\hline
\end{tabular}

weight and the mass of internal organs of the experimental animals were similar to those of the control groups (Table 7).

The macroscopic examination of the internal organs of the animals in 7 days after the beginning of the experiment did not reveal any pathological changes (data not shown). Concentrations of erythrocytes and leukocytes in the peripheral blood of the control and experimental mice varied within physiological norm (Table 8). No significant shifts were revealed in the leukocyte formula of the blood of the animals of experimental group.

\section{Conclusion}

It was found, that the contact of $\mathrm{P}(3 \mathrm{HB}$ co-4HB) membranes did not reduce the biological value of human blood cells, did not change the content of hemoglobin in blood, was not accompanied by changes in the hemolytic activity of isolated red blood cells in vitro also. In the in vivo experiments no toxic effects of membranes were revealed. According to the studied parameters, non-woven membranes from $\mathrm{P}(3 \mathrm{HB}-\mathrm{co}-4 \mathrm{HB})$ could be use as scaffold materials for regeneration and bioengineering of skin. 


\section{Acknowledgements}

The reported study was funded by RFBR and Government of Krasnoyarsk Territory according to the research project № 16-43-242024; investigations of blood - by the State budget allocated to the fundamental research at the Russian Academy of Sciences (№ AAAA-A17117013050028-8).

\section{Referenses}

GOST R ISO 10993-2-2009. Medical products. Evaluation of the biological influence of medical products. Part 2. Requirements for animals handling. (in Russian)

GOST R ISO 10993-4-2011. Medical products. Evaluation of the biological influence of medical products. Part 4. The study of products, interacting with blood. (in Russian)

GOST R ISO 10993-11-2011. Medical products. Evaluation of the biological influence of medical products. Part 11. Study of general toxic effect. (in Russian)

Harboe M.A. (1959) Method for determination hemoglobin in plasma by near-ultraviolet spectrophotometry. Scand J Clin Lab Invest, 11: 66-70

Khubutija M.S., Makarov M.S., Khvatov V.B., Vysochin I.V., Kobzeva E.N., Borovkova N.V., Konjushko O.I. (2013) Method for assessing morphofunctional status of human thrombosytes. Patent RF № 2485502 by 20.06.2013. (in Russian)

Sharma K., Bullock A., Ralston D., MacNeil S. (2014) Development of a one-step approach for the reconstruction of full-thickness skin defects using minced split thickness skin grafts and biodegradable synthetic scaffolds as a dermal substitute. Burns, 40(5): 957-965

Sill T.J., von Recum H.A. (2008) Electrospinning: applications in drug delivery and tissue engineering. Biomaterials, 29(13): 1989-2006 